\title{
The Contribution of MMP-7 Promoter Polymorphisms to Taiwan Lung Cancer Susceptibility
}

\author{
GUAN-LIANG CHEN ${ }^{1,2,3}$, TE-CHUN SHEN ${ }^{4}$, WEN-SHIN CHANG $^{4}$, CHIA-WEN TSAI $^{4}$, \\ HSIN-TING LI ${ }^{1,4}$, CHIH-LIANG CHUANG ${ }^{2,3}$, YI-LIANG LAI ${ }^{2,3}$, TE-CHENG YUEH ${ }^{1,2,3}$, \\ TE-CHUN HSIA ${ }^{4 *}$, SHOU-CHENG WANG ${ }^{2,3^{*}}$ and DA-TIAN BAU ${ }^{1,4,5^{*}}$ \\ ${ }^{1}$ Graduate Institute of Biomedical Sciences, China Medical University, Taichung, Taiwan, R.O.C.; \\ ${ }^{2}$ Taichung Armed Forces General Hospital, Taichung, Taiwan, R.O.C.; \\ ${ }^{3}$ National Defense Medical Center, Taipei, Taiwan, R.O.C.; \\ ${ }^{4}$ Terry Fox Cancer Research Laboratory, Translational Medicine Research Center, \\ China Medical University Hospital, Taichung, Taiwan, R.O.C.; \\ ${ }^{5}$ Department of Bioinformatics and Medical Engineering, Asia University, Taichung, Taiwan, R.O.C.
}

\begin{abstract}
Background/Aim: Matrix metalloproteinase-7 (MMP-7) plays an important role in metastasis behavior of cancer cells, and overexpression of MMP-7 has been associated with poor prognosis in non-small cell lung cancer. However, the contribution of various genotypes of MMP-7 has not yet been investigated in lung cancer in Taiwan. Therefore, this study aimed to investigate the association of MMP-7 genotypes with lung cancer risk among the Taiwanese. Materials and Methods: In this hospital-based case-control study, genotypes and distributions at two promoter sites of MMP-7, A-181G and C-153T, were determined, and their association with lung cancer risk in Taiwan was evaluated among 358 lung cancer patients and 716 age- and gender-matched healthy control individuals. In addition, the interaction of MMP-7 genotypes and smoking status were also examined. Results: The percentages of variant $A G$ and $G G$ at MMP-7 A-181G in the lung cancer group were similar to the control group $(12.8 \%$ and $2.3 \%$ vs. $11.3 \%$ and $1.5 \%$, respectively; $\left.p_{\text {trend }}=0.5294\right)$. The allelic frequency distribution analysis showed that the variant $G$ allele at MMP-7 A-181G conferred non-significant elevated lung cancer risk compared to the wild-type A allele [odds ratio $(O R)=1.18,95 \%$ confidence interval $(C I)=0.85-1.66$,
\end{abstract}

\footnotetext{
*These Authors contributed equally to this study.

Correspondence to: Da-Tian Bau, Terry Fox Cancer Research Laboratory, Translational Medicine Research Center, China Medical University Hospital, 2 Yuh-Der Road, Taichung, 404 Taiwan, ROC. Tel.: +886 422053366 (Ext. 5805), e-mail: datian@mail.cmuh.org.tw; artbau2@gmail.com
}

Key Words: Lung cancer, genotype, MMP-7, polymorphism, Taiwan. $p=0.2289]$. As for the genotypes of MMP-7 C-153T, all the studied Taiwanese population was of CC genotype. Furthermore, there was no obvious joint effect of MMP-7 A$181 G$ genotype and smoking status on the lung cancer risk. No statistically significant correlation was observed between MMP-7 A-181G genotype distributions and gender. Conclusion: There was no evidence that the genotypes of MMP-7 A-181G may act as a biomarker in determining personal susceptibility to lung cancer in Taiwan.

For many decades, lung cancer has been the most common and death-causing cancer worldwide, estimated to be responsible for about one in five of cancer deaths $(1,2)$. During the past years, despite the rapid development of precise medicine and personalized therapies, the overall 5 -year survival rate for lung cancer patients remained less than 20\% (3). Thus, searching and revealing of novel predictive and prognostic markers are still in urgent need, and should be validated in different populations with different genetic backgrounds.

Matrix metalloproteinases (MMPs), also named as matrixins, have been identified to play a central role in proteolysis of the extracellular matrix (ECM) molecules (46). In addition to be involved in embryonic development, reproduction, and tissue resorption and remodeling, MMPs are implicated in many tumorigenesis events, such as cell proliferation, differentiation, apoptosis, invasion, migration, metastasis, angiogenesis, and immune surveillance (7). From the viewpoint of cancer genomics, during the past years, several polymorphic genotypes of $M M P$ family genes, especially those implicated in the regulation of gene expression, have been reported to be significantly associated with the inter-individual differences of susceptibility to several types of cancer (8-16), while some others have not 
Table I. Distribution of selected demographics of the 358 patients with lung cancer and the 716 matched controls.

\begin{tabular}{|c|c|c|c|c|c|c|c|}
\hline \multirow[t]{2}{*}{ Characteristics } & \multicolumn{3}{|c|}{ Controls $(n=716)$} & \multicolumn{3}{|c|}{ Patients $(\mathrm{n}=358)$} & \multirow[t]{2}{*}{$p$-Value } \\
\hline & $\mathrm{n}$ & $\%$ & Mean (SD) & $\mathrm{n}$ & $\%$ & Mean (SD) & \\
\hline Age (years) & & & $64.8(6.8)$ & & & $64.0(6.9)$ & 0.5871 \\
\hline \multicolumn{8}{|l|}{ Gender } \\
\hline Male & 488 & $68.1 \%$ & & 254 & $70.9 \%$ & & \\
\hline Female & 228 & $31.9 \%$ & & 104 & $29.1 \%$ & & 0.3642 \\
\hline \multicolumn{8}{|l|}{ Smoking status } \\
\hline Ever smokers & 563 & $78.6 \%$ & & 293 & $81.8 \%$ & & \\
\hline Non-smokers & 153 & $21.4 \%$ & & 65 & $18.2 \%$ & & 0.2282 \\
\hline \multicolumn{8}{|l|}{ Histology } \\
\hline Adenocarcinoma & & & & 218 & $60.9 \%$ & & \\
\hline $\mathrm{SCC}$ & & & & 106 & $29.6 \%$ & & \\
\hline Other & & & & 34 & $9.5 \%$ & & \\
\hline
\end{tabular}

SCC, Squamous cell carcinoma; SD, standard deviation. aBased on Chi-square test.

(17-19). The biomarkers are very helpful in early detection and prediction of personalized cancer susceptibility.

MMP-7 (also named as matrilysin, pump-1 protease) is the smallest member of the MMPs $(28 \mathrm{kDa})$ in the human body. Constitutively, MMP-7 is produced by the epithelial cells of various tissues including mammary and parotid glands, pancreas, liver, prostate, and most important, the peribronchial glands of lung (20). It is involved of the proteolysis of various substrates in ECM including elastin, casein, type I, II, IV, and $\mathrm{V}$ gelatins, fibronectin, and proteoglycan (21-23). Activated MMP-7 may be involved in facilitating tumor invasion via cleaving the pro-peptides of pro-MMP-2 and pro-MMP-9 (24). MMP-7-deficient mice showed significantly reduced tumor multiplicity and body growth (25).

MMP-7 localized on human chromosome 11q21-q22 and two of its polymorphic sites, A-181G (rs11568818) and C153T (rs11568819), were reported to exert allele-specific regulation of its expression. Briefly, the promoter assay showed that promoter constructs harboring the combination of the two variant alleles at MMP-7 A-181G and C-153T were of higher expression than other constructs (26). Several association studies have investigated the association of the genotypes at $M M P-7$ polymorphic sites with several types of cancer, including oral, breast, esophageal, gastric, colorectal, gallbladder, bladder, cervical cancer, astrocytoma, childhood leukemia, and renal cell carcinoma (16, 18, 27-37).

As for lung cancer, there were at least two important studies investigating the association of MMP-7 genotypes with lung cancer risk $(38,39)$. In 2005, Zhang and his colleagues found that $\mathrm{G}$ allele at MMP-7 A-181G was associated with significantly increased susceptibility to nonsmall cell lung carcinoma (NSCLC) (38). They also showed that smoking status did not significantly influence the association between the MMP-7-181A/G polymorphism and NSCLC (38). On the contrary, Sanli and his colleagues found that different $M M P-7 \mathrm{~A}-181 \mathrm{G}$ genotypes may not contribute to altered lung cancer risk in 2013 (39). The two papers were investigating Han and Caucasian populations, respectively, and it is very reasonable to explain the differences between their findings by the fact that there were differential influences of $M M P-7$ genotypes on individual lung cancer risk among different racial populations/ethnicities. Thus, more investigations on different populations are needed to figure out the contribution of $M M P-7$ genotypes to lung cancer risk. In light of the above, we conducted a hospitalbased study to examine the genotypes of $M M P-7$ among Taiwanese and reveal the contribution of $M M P-7$ promoter genotypes to the Taiwanese lung cancer risk.

\section{Materials and Methods}

Patient collection. Three hundred and fifty-eight patients with lung cancer were histologically confirmed and recruited at the medical center in central Taiwan, as previously described, with the approval of the Institutional Review Board of China Medical University Hospital (DMR100-IRB-284) (19, 40, 41). Briefly, the exclusion criteria of the cases included history of any other malignancy and pulmonary diseases, such as chronic obstructive pulmonary disease (COPD), pneumothorax, and asthma. During the same period, 760 healthy volunteers were selected from the databank of Health Examination Cohort of China Medical University Hospital with more than 15,000 individuals as controls, matched for their age (differences less than 5), gender, and smoking behavior. The exclusion criteria of the control group included previous malignancy, metastasized cancer from other known or unknown origin, and any genetic or familial diseases. The control and case individuals are all Taiwanese and their selected recorded characteristics are summarized in Table I. 
Concise MMP-7 genotyping methodologies. After providing their inform consents, $3-5 \mathrm{ml}$ of blood were collected from all the recruited individuals. On the same day, genomic DNA was extracted from peripheral blood leukocytes with the QIAamp Blood Mini Kit (Qiagen, Taipei, Taiwan), stored long-term at $-80^{\circ} \mathrm{C}$, diluted and aliquoted for genotyping as a working stock at $-20^{\circ} \mathrm{C}(42-44)$. The methodology for $M M P-7$ genotype determination including the design of specific primers and the selection of restriction enzymes for MMP-7 A-181G (rs11568818) and C-153T (rs11568819) was exactly the same as our currently published papers $(16,18,37,45)$. The polymerase chain reaction (PCR) cycling conditions were set as one cycle at $94^{\circ} \mathrm{C}$ for $5 \mathrm{~min} ; 35$ cycles of $94^{\circ} \mathrm{C}$ for $30 \mathrm{~s}, 59^{\circ} \mathrm{C}$ for $30 \mathrm{~s}$ and $72^{\circ} \mathrm{C}$ for $30 \mathrm{~s}$, and a final extension cycle at $72^{\circ} \mathrm{C}$ for 10 $\min$. The sequences of forward and reverse primers for $M M P-7 \mathrm{~A}$ $181 \mathrm{G}$ were 5'-TGGTACCATAATGTCCTGAATG-3' and 5'TCGTTATTGGCAGGAAGCACACAATGAATT-3', respectively. The obtained $150 \mathrm{bp}$ PCR products were digested with 1 unit of EcorI resulting in $120 \mathrm{bp}$ and $30 \mathrm{bp}$ fragments when the $\mathrm{G}$ allele was present, while remained intact when the A allele was present After amplification, the PCR products were subject to digestion and separation using 3\% agarose gel electrophoresis. As for MMP-7 C153T, direct sequencing PCR was conducted and double checked with the same primer pairs as for MMP-7 A-181G. All the genotypic processing was independently and blindly repeated by at least two expert researchers listed in acknowledgement, and the results were $100 \%$ concordant to each other. The success rate of PCR-restrictive fragment length polymorphism was $100 \%$.

Statistical analyses. The Student's $t$-test was applied for the comparison of age between the lung cancer and the control groups. Pearson's Chi-square or Fisher's exact test (when $n<5$ ) was applied to compare the distributions of the numbers among the subgroups. The associations between $M M P-7$ genotypes and lung cancer risk were estimated by calculating the odds ratios (ORs) and their $95 \%$ confidence intervals (CIs) from logistic regression analysis. Statistically, any difference at $p<0.05$ was considered as significant

\section{Results}

The frequency distributions of selected demographic characteristics, such as age and gender, for the 358 cases of lung cancer and 716 non-cancer healthy controls were compared and presented in Table I. As for the lung cancer group, the histology of all the patients was also recorded Since frequency matching was applied in recruiting the noncancer healthy individuals as the control group, the analysis results showed that there was no difference in respect to the distributions of age and gender between the control and case groups $(p=0.5871$ and 0.3642 , respectively; Table I). About three-fifth of the lung cancer patients $(60.9 \%, 218$ out of 358 ) were of adenocarcinoma type, while $29.6 \%$ (106 out of 358 ) were of squamous cell carcinoma type, and $9.5 \%$ (34 out of 358) were of other types (Table I).

The distributions and frequencies of the MMP-7 A-181G and C-153T genotypes of the 358 lung cancer patients (cases) and the 716 non-cancer healthy subjects (controls) were analyzed and presented in Table II. First, contrary to the Caucasian populations (46), the genotyping results showed that
Table II. Distributions of matrix metalloproteinase-7 A-181G and C$153 T$ genotype frequencies among lung cancer patients and healthy individuals.

\begin{tabular}{lcccc}
\hline & $\begin{array}{c}\text { Cases, } \\
\mathrm{n}(\%)\end{array}$ & $\begin{array}{c}\text { Controls, } \\
\mathrm{n}(\%)\end{array}$ & $\begin{array}{c}\text { Adjusted OR } \\
(95 \% \mathrm{CI})^{\mathrm{a}}\end{array}$ & $p$-Value ${ }^{\mathrm{b}}$ \\
\hline $\mathrm{A}-181 \mathrm{G}$ & & & & \\
$\mathrm{AA}$ & $304(84.9)$ & $624(87.2)$ & 1.00 (Reference) & \\
$\mathrm{AG}$ & $46(12.8)$ & $81(11.3)$ & $1.19(0.77-1.85)$ & 0.4371 \\
$\mathrm{GG}$ & $8(2.3)$ & $11(1.5)$ & $1.49(0.63-3.62)$ & 0.3909 \\
$\mathrm{AG}+\mathrm{GG}$ & $54(15.1)$ & $92(12.8)$ & $1.23(0.88-1.74)$ & 0.3138 \\
$p_{\text {trend }}$ & & & & 0.5294 \\
$\mathrm{C}-153 \mathrm{~T}$ & & & & \\
$\mathrm{CC}$ & $358(100.0)$ & $716(100.0)$ & $1.00($ Reference) & \\
$\mathrm{CT}$ & $0(0.0)$ & $0(0.0)$ & -- & \\
TT & $0(0.0)$ & $0(0.0)$ & -- & \\
$p_{\text {trend }}$ & & & & \\
\hline
\end{tabular}

OR, Odds ratio; CI, confidence interval. aData have been adjusted for confounding factors age, gender, and smoking; bBased on Chi-square test without Yates' correction.

Table III. Allelic frequencies for matrix metalloproteinase-7 A-181G and $C-153 T$ polymorphisms among the lung cancer patients and healthy subjects.

\begin{tabular}{ccccc}
\hline Allelic type & $\begin{array}{c}\text { Cases, } \\
\mathrm{n}(\%) \\
\mathrm{n}=716\end{array}$ & $\begin{array}{c}\text { Controls, } \\
\mathrm{n}(\%) \\
\mathrm{n}=1432\end{array}$ & $\begin{array}{c}\text { Adjusted OR } \\
(95 \% \mathrm{CI})^{\mathrm{a}}\end{array}$ & $p$-Value $^{\mathrm{b}}$ \\
\hline A-181G & & & & \\
Allele A & $654(91.3)$ & $1329(92.8)$ & 1.00 (Reference) & 0.2289 \\
Allele G & $62(8.7)$ & $103(7.2)$ & $1.18(0.85-1.66)$ & \\
C-153T & & & 1.00 (Reference) & \\
Allele C & $716(100.0)$ & $1432(100.0)$ & -- & \\
Allele T & $0(0.0)$ & $0(0.0)$ & - & \\
\hline
\end{tabular}

OR, Odds ratio; CI, confidence interval. aData have been adjusted for confounding factors age, gender, and smoking; ${ }^{b}$ Based on Chi-square test without Yates' correction.

the genotype of $M M P-7 \mathrm{C}-153 \mathrm{~T}$ was the same in all the studied population with no variant detected (Table II). Second, the genotypes of $M M P-7 \mathrm{~A}-181 \mathrm{G}$ were not differently distributed between the two groups ( $p=0.5294$; Table II). In detail, the MMP-7 A-181G homozygous GG and heterozygous AG were not associated with elevated lung cancer risk (adjusted $\mathrm{OR}=1.49,95 \% \quad \mathrm{CI}=0.88-1.74, \quad p=0.3909$ and adjusted $\mathrm{OR}=1.19,95 \% \quad \mathrm{CI}=0.63-3.62, \quad p=0.4371$, respectively) compared to wild-type AA genotype (Table II). To confirm this finding, there was also no association between the $\mathrm{AG}+\mathrm{GG}$ genotype of $M M P-7 \mathrm{~A}-181 \mathrm{G}$ and lung cancer risk, compared to AA wild-type genotype in the dominant analyzing model, (adjusted $\mathrm{OR}=1.23,95 \% \mathrm{CI}=0.88-1.74, p=0.3138$; Table II). 
Table IV. Odds ratios for matrix metalloproteinase-7 A-181G genotype and lung cancer after stratification by smoking status.

\begin{tabular}{|c|c|c|c|c|c|c|c|c|c|c|}
\hline \multirow[t]{2}{*}{ Genotype } & \multicolumn{2}{|c|}{ Non-smokers, $\mathrm{n}$} & \multirow{2}{*}{$\begin{array}{c}\text { OR } \\
(95 \% \mathrm{CI})^{\mathrm{a}}\end{array}$} & \multirow{2}{*}{$\begin{array}{c}\mathrm{aOR} \\
(95 \% \mathrm{CI})^{\mathrm{b}}\end{array}$} & \multirow[t]{2}{*}{$p$-Value ${ }^{c}$} & \multicolumn{2}{|c|}{ Smokers, $\mathrm{n}$} & \multirow{2}{*}{$\begin{array}{c}\text { OR } \\
(95 \% \mathrm{CI})^{\mathrm{a}}\end{array}$} & \multirow{2}{*}{$\begin{array}{c}\mathrm{aOR} \\
(95 \% \mathrm{CI})^{\mathrm{b}}\end{array}$} & \multirow[t]{2}{*}{$p$-Value } \\
\hline & Controls & Cases & & & & Controls & Cases & & & \\
\hline $\mathrm{AA}$ & 133 & 54 & $1.00(\mathrm{ref})$ & 1.00 (ref) & & 491 & 250 & 1.00 (ref) & 1.00 (ref) & \\
\hline $\mathrm{AG}$ & 17 & 8 & $1.16(0.47-2.84)$ & $1.27(0.56-3.28)$ & 0.7472 & 64 & 38 & $1.17(0.76-1.79)$ & $1.14(0.63-1.68)$ & 0.4826 \\
\hline GG & 3 & 3 & $2.46(0.48-12.59)$ & $3.05(0.51-10.92)$ & 0.2642 & 8 & 5 & $1.23(0.40-3.79)$ & $1.31(0.50-3.82)$ & 0.7212 \\
\hline$p_{\text {trend }}$ & & & & & 0.5210 & & & & & 0.7417 \\
\hline Total & 153 & 65 & & & & 563 & 293 & & & \\
\hline
\end{tabular}

$\mathrm{CI}$, Confidence interval; aOR, adjusted odds ratio. ${ }^{\mathrm{B} B y}$ multivariate logistic regression analysis; ${ }^{\mathrm{b}} \mathrm{By}$ multivariate logistic regression analysis after adjusted of age and gender status; 'Based on Chi-square test without Yates' correction.

To further confirm the results for the genotype frequency distributions (Table II), analysis of allelic frequency distribution for the MMP-7 A-181G and C-153T was also conducted and the results are shown in Table III. It was demonstrated that neither the genotype of MMP-7 A-181G, nor that of C-153T was associated with lung cancer risk. In detail, the variant allele $\mathrm{G}$ was found at $8.7 \%$ of the lung cancer cases and at $7.2 \%$ of the control group (adjusted $\mathrm{OR}=1.18,95 \% \mathrm{CI}=0.85-1.66, p=0.2289$; Table III). As for $M M P-7$ C-153T, there was no variant $\mathrm{T}$ allele found in any of the examined individuals (Table III).

Since cigarette smoking behavior is one of the well-known risk factors for lung cancer in Taiwan (47), the possible interaction between the MMP-7 A-181G genotype and personal smoking behavior was investigated, and the results are shown in Table IV. Among the non-smokers, there was no significant increased risk of lung cancer for AG and GG genotype carriers $(\mathrm{OR}=1.16,95 \% \mathrm{CI}=0.47-2.84, p=0.7472$ and $\mathrm{OR}=2.46,95 \% \mathrm{CI}=0.48-12.59, p=0.2642$, respectively, $p_{\text {trend }}=0.5210$ ) (Table IV, left part). Similarly, there was found no significant association between $A G$ and $G G$ genotypes and lung cancer risk among smokers (Table IV). After adjusting for age and gender, the results were all the same in both non-smoker and smoker groups with negative findings (Table IV). In addition, due to the high death rates of Taiwanese female non-small cell adenocarcinoma lung cancer patients (48), the potential differential contribution of $M M P-7$ A-181G to males and females was investigated. However, there was no interaction between gender and $M M P-7$ A-181G genotypes on lung cancer susceptibility in the Taiwan population (data not shown).

\section{Discussion}

In the current paper, the contribution of MMP-7 genotypes to lung cancer risk was investigated in Taiwan, where the lung cancer is the highest death-causing cancer according to the national statistics (48). The promoter polymorphisms at $M M P$ 7 have been reported to affect its expression (26), and herein, it was shown that neither the wild-type A nor the variant $G$ allele at the MMP7 A-181G were associated with increased risk of lung cancer in Taiwanese (Tables II and III). Interestingly, no variant genotypes of $M M P-7 \mathrm{C}-153 \mathrm{~T}$ were detected among the studied population (Tables II and III). As far as we know, this is the first paper to investigate the contribution of MMP-7 genotypes to lung cancer risk in Taiwanese population. In 2010, the same polymorphic MMP-7 sites (C-153T and A-181G) were examined among 349 Caucasian lung cancer patients, about their role in prediction of chemotherapy outcome, including response after the second cycle, progression-free survival (PFS), and overall survival (OS) (46). Although their findings in associating the genotypes of $M M P-1,-2,-3,-7,-9$ or -12 with lung cancer prognosis were all negative, the group reported that the combined variant alleles, which lead to an enhanced expression of $M M P-7$ in the plasma (26), were associated with a longer lifetime of lung cancer patients with squamous carcinoma after starting chemotherapy, compared to lung cancer patients carrying other $M M P-7$ genotypes (46). In the present study, we have collected a number of lung cancer patients, and a nearly double number of healthy individuals as controls, in Taiwan. However, the predictive and prognostic potential of $M M P-7$ genotypes in lung cancer patients was not investigated, neither the expression level of MMP-7 in the plasma nor the genotype-phenotype correlation of MMP-7 were evaluated in our population.

MMP-7 has also been implicated in lung cancer invasion metastasis. More specifically, it has been shown that downregulation fibulin-5, a metastatic suppressor for lung cancer, can activate MMP-7 via ERK pathway and subsequently promote lung cancer cell invasion (49). Thus, MMP-7 genotypes may be a novel biomarker for early prediction of poor disease prognosis in addition to lung cancer risk. However, the genotypes at $M M P-7$ promoter region (C-153T and A-181G) were not predictive of either lung cancer 
susceptibility or prognosis (46). The two MMP-7 promoter SNPs were not proved to be predictive biomarkers for oral cancer (50), childhood leukemia (37), or breast cancer in Taiwan either (16). The above findings suggest that studies should focus on the predictive capacity of $M M P$ genes, except $M M P-7$, in lung cancer risk or prognosis, taking into account their involvement in multiple pathways and networks. The genotypes of $M M P-7$ may play a minor role in determination of lung cancer susceptibility. In 2017, Jung and his colleagues examined the feasibility and accuracy of lung cancer detection using a 7-protein biomarker panel. They reported that EGFR1, MMP7, CA6, KIT, CRP, C9, and SERPINA3 served well in study cohort of 100 Korean lung cancer patients and 100 control individuals (51).

The smoking behaviors are risk factors for various types of cancer worldwide, and the efforts from the WHO Framework Convention on Tobacco Control have suppressed the smoking prevalence for 126 countries from $24.73 \%$ in 2005 to $22.18 \%$ in 2015 , with an average decrease in prevalence of 2.55 percentage points worldwide (52). In our population, obviously smoking status was a risk factor for lung cancer, since the percentages of smokers in the case group was as high as $81.8 \%$. However, the case group was matched to the control group not only by age and gender, but also by smoking status; therefore, the percentage of smokers in the control group was also very high (78.6\%) (Table I). In fact, the government has prohibited the smoking behavior in public since 1997 and the percentages of ever smokers in Taiwan have been significantly lowered from $32.5 \%$ in 1990 to $15.3 \%$ in 2016 . Therefore, it is expected that the prevalence of smoking and associated consequences, such as lung cancer risk, may be reduced in Taiwan in the near future. However, the elevation in thermal power generation and the air pollution with particulate matter less than $2.5 \square \mathrm{m}$ may serve as a new risk factor for lung cancer in Taiwan (53).

The biological function of MMPs apparently is more complex than their proved involvement in the control of tumor cell proliferation and metastasis $(54,55)$. In 2007, the mRNA expression level of MMP-7 was found to be higher in NSCLC tissues than normal controls; however, the expression levels of MMP-7 protein were not studied (56). Correlation of patient status, genotype, and phenotype would be very helpful to reveal the role of MMPs, especially MMP-7, in lung cancer progress and prognosis. Although power analysis was performed for the current study and representativeness was examined as well, a larger number of cases would be necessary to further examine the contributions of specific genotypes in lung cancer risk and prognosis, according to patient characteristics, such as gender and smoking status.

In conclusion, the genotypes A-181G and C-153T at MMP7 promoter region were not shown to serve as useful biomarker for lung cancer risk prediction in the studied Taiwanese population. In addition, no joint effects of $M M P-7$ genotypes and smoking status on lung cancer susceptibility were observed.

\section{Acknowledgements}

The Authors declare no conflict of interest in regard to this study. We appreciate the Tissue-bank of China Medical University Hospital for their excellent technical assistance and all the individuals, doctors, nurses, and colleagues. The excellent genotyping work, partly performed by Huai-Mei Hsu and Yun-Chi Wang in Terry Fox Cancer Research Lab, was also appreciated by all the authors. This study was supported mainly by the Taiwan Ministry of Science and Technology (MOST 106-2314-B-039-022) to Dr. Hsia and (MOST 106-2314-B-039-011) to Dr. Shen, and Taichung Armed Forces General Hospital (106A04 and 107A02) to Dr. Wang and (107A03) to Dr. Chen.

\section{References}

1 Jemal A, Bray F, Center MM, Ferlay J, Ward E and Forman D: Global cancer statistics. CA Cancer J Clin 61: 69-90, 2011.

2 Siegel RL, Miller KD and Jemal A: Cancer statistics, 2017. CA Cancer J Clin 67: 7-30, 2017.

3 Siegel RL, Miller KD and Jemal A: Cancer statistics, 2015. CA Cancer J Clin 65: 5-29, 2015.

4 de Souza AP, Trevilatto PC, Scarel-Caminaga RM, Brito RB and Line SR: MMP-1 promoter polymorphism: association with chronic periodontitis severity in a Brazilian population. J Clin Periodontol 30: 154-158, 2003.

5 Werb Z: ECM and cell surface proteolysis: regulating cellular ecology. Cell 91: 439-442, 1997.

6 Sternlicht MD and Werb Z: How matrix metalloproteinases regulate cell behavior. Annu Rev Cell Dev Biol 17: 463-516, 2001.

7 Egeblad $\mathrm{M}$ and Werb $\mathrm{Z}$ : New functions for the matrix metalloproteinases in cancer progression. Nat Rev Cancer 2: 161-174, 2002.

8 Tsai CW, Chang WS, Gong CL, Shih LC, Chen LY, Lin EY, Li HT, Yen ST, Wu CN and Bau DT: Contribution of matrix metallopeptidase-1 genotypes, smoking, alcohol drinking and areca chewing to nasopharyngeal carcinoma susceptibility. Anticancer Res 36: 3335-3340, 2016.

9 Sun KT, Tsai CW, Chang WS, Shih LC, Chen LY, Tsai MH, Ji HX, Hsiao CL, Liu YC, Li CY and Bau DT: The contribution of matrix metalloproteinase-1 genotype to oral cancer susceptibility in Taiwan. In Vivo 30: 439-444, 2016.

10 Price SJ, Greaves DR and Watkins H: Identification of novel, functional genetic variants in the human matrix metalloproteinase2 gene: role of $\mathrm{Sp} 1$ in allele-specific transcriptional regulation. $\mathrm{J}$ Biol Chem 276: 7549-7558, 2001.

11 Ye S: Polymorphism in matrix metalloproteinase gene promoters: implication in regulation of gene expression and susceptibility of various diseases. Matrix Biol 19: 623-629, 2000.

12 Yu C, Zhou Y, Miao X, Xiong P, Tan W and Lin D: Functional haplotypes in the promoter of matrix metalloproteinase-2 predict risk of the occurrence and metastasis of esophageal cancer. Cancer Res 64: 7622-7628, 2004.

13 Elander N, Soderkvist P and Fransen K: Matrix metalloproteinase (MMP) $-1,-2,-3$ and -9 promoter polymorphisms in colorectal cancer. Anticancer Res 26: 791-795, 2006. 
14 Li Y, Jin X, Kang S, Wang Y, Du H, Zhang J, Guo W, Wang N and Fang S: Polymorphisms in the promoter regions of the matrix metalloproteinases- $1,-3,-7$, and -9 and the risk of epithelial ovarian cancer in China. Gynecol Oncol 101: 92-96, 2006.

$15 \mathrm{Hu}$ Z, Huo X, Lu D, Qian J, Zhou J, Chen Y, Xu L, Ma H, Zhu J, Wei $Q$ and Shen H: Functional polymorphisms of matrix metalloproteinase- 9 are associated with risk of occurrence and metastasis of lung cancer. Clin Cancer Res 11: 5433-5439, 2005.

16 Chou AK, Hsiao CL, Shih TC, Wang HC, Tsai CW, Chang WS, Liu LC, Way TD, Chung JG and Bau DT: The Contribution of matrix metalloproteinase-7 promoter genotypes in breast cancer in Taiwan. Anticancer Res 37: 4973-4977, 2017.

17 Hung YW, Tsai CW, Wu CN, Shih LC, Chen YY, Liu YF, Hung HS, Shen MY, Chang WS and Bau DT: The Contribution of matrix metalloproteinase- 8 promoter polymorphism to oral cancer susceptibility. In Vivo 31: 585-590, 2017.

18 Liao CH, Chang WS, Hu PS, Wu HC, Hsu SW, Liu YF, Liu SP, Hung HS, Bau DT and Tsai CW: The Contribution of MMP-7 promoter polymorphisms in renal cell carcinoma. In Vivo 31: 631-635, 2017.

19 Shen TC, Hsia TC, Chao CY, Chen WC, Chen CY, Chen WC, Lin YT, Hsiao CL, Chang WS, Tsai CW and Bau DT: The contribution of MMP-8 promoter polymorphisms in lung cancer. Anticancer Res 37: 3563-3567, 2017.

20 Saarialho-Kere UK, Crouch EC and Parks WC: Matrix metalloproteinase matrilysin is constitutively expressed in adult human exocrine epithelium. J Invest Dermatol 105: 190-196, 1995.

21 Woessner JF Jr. and Taplin CJ: Purification and properties of a small latent matrix metalloproteinase of the rat uterus. J Biol Chem 263: 16918-16925, 1988

22 Miyazaki K, Hattori Y, Umenishi F, Yasumitsu H and Umeda M: Purification and characterization of extracellular matrix-degrading metalloproteinase, matrin (pump-1), secreted from human rectal carcinoma cell line. Cancer Res 50: 7758-7764, 1990.

23 Yokoyama Y, Grunebach F, Schmidt SM, Heine A, Hantschel M, Stevanovic S, Rammensee HG and Brossart P: Matrilysin (MMP-7) is a novel broadly expressed tumor antigen recognized by antigen-specific T cells. Clin Cancer Res 14: 5503-5511, 2008.

24 Edman K, Furber M, Hemsley P, Johansson C, Pairaudeau G, Petersen J, Stocks M, Tervo A, Ward A, Wells E and Wissler L: The discovery of MMP7 inhibitors exploiting a novel selectivity trigger. ChemMedChem 6: 769-773, 2011.

25 Wilson CL, Heppner KJ, Labosky PA, Hogan BL and Matrisian LM: Intestinal tumorigenesis is suppressed in mice lacking the metalloproteinase matrilysin. Proc Natl Acad Sci USA 94: 14021407, 1997.

26 Jormsjo S, Whatling C, Walter DH, Zeiher AM, Hamsten A and Eriksson P: Allele-specific regulation of matrix metalloproteinase- 7 promoter activity is associated with coronary artery luminal dimensions among hypercholesterolemic patients. Arterioscler Thromb Vasc Biol 21: 1834-1839, 2001.

27 Lu Z, Wang Y, Zhang Q, Zhang X, Wang S, Xie H, Li Y, Jiao B and Zhang J: Association between the functional polymorphism in the matrix metalloproteinase-7 promoter and susceptibility to adult astrocytoma. Brain Res 1118: 6-12, 2006.

28 Malik MA, Sharma KL, Zargar SA and Mittal B: Association of matrix metalloproteinase-7 $(-181 \mathrm{~A}>\mathrm{G})$ polymorphism with risk of esophageal squamous cell carcinoma in Kashmir Valley. Saudi J Gastroenterol 17: 301-306, 2011.
29 Fang WL, Liang WB, Gao LB, Zhou B, Xiao FL and Zhang L: Genetic polymorphisms in matrix metalloproteinases -1 and -7 and susceptibility to gastric cancer: an association study and metaanalysis. Iran J Allergy Asthma Immunol 12: 203-210, 2013.

30 Moreno-Ortiz JM, Gutierrez-Angulo M, Partida-Perez M, Peregrina-Sandoval J, Ramirez-Ramirez R, Muniz-Mendoza R, Suarez-Villanueva S, Centeno-Flores M, Maciel-Gutierrez V, Cabrales-Vazquez JE and Ayala-Madrigal ML: Association of MMP7-181A/G and MMP13-77A/G polymorphisms with colorectal cancer in a Mexican population. Genet Mol Res 13: 3537-3544, 2014.

31 Sharma KL, Misra S, Kumar A and Mittal B: Higher risk of matrix metalloproteinase (MMP-2, 7, 9) and tissue inhibitor of metalloproteinase (TIMP-2) genetic variants to gallbladder cancer. Liver Int 32: 1278-1286, 2012.

32 Horvat M, Potocnik U, Repnik K, Kavalar R, Zadnik V, Potrc S and Stabuc B: Single Nucleotide Polymorphisms in genes MACC1, RAD18, MMP7 and SDF-1a as prognostic factors in resectable colorectal cancer. Radiol Oncol 51: 151-159, 2017.

33 Wieczorek E, Reszka E, Wasowicz W, Grzegorczyk A, Konecki T, Sosnowski M and Jablonowski Z: MMP7 and MMP8 genetic polymorphisms in bladder cancer patients. Cent European J Urol 66: 405-410, 2014.

34 Xie B, Zhang Z, Wang H, Chen Z, Wang Y, Liang H, Yang G, Yang $X$ and Zhang H: Genetic polymorphisms in MMP 2, 3, 7, and 9 genes and the susceptibility and clinical outcome of cervical cancer in a Chinese Han population. Tumour Biol 37: 4883-4888, 2016.

35 Lievre A, Milet J, Carayol J, Le Corre D, Milan C, Pariente A, Nalet B, Lafon J, Faivre J, Bonithon-Kopp C, Olschwang S, Bonaiti-Pellie C, Laurent-Puig P and members of the Ag: Genetic polymorphisms of MMP1, MMP3 and MMP7 gene promoter and risk of colorectal adenoma. BMC Cancer 6: 270, 2006.

36 Vairaktaris E, Serefoglou Z, Yapijakis C, Vylliotis A, Nkenke E, Derka S, Vassiliou S, Avgoustidis D, Neukam FW and Patsouris E: High gene expression of matrix metalloproteinase-7 is associated with early stages of oral cancer. Anticancer Res 27: 2493-2498, 2007.

37 Pei JS, Chou AK, Hsu PC, Tsai CW, Chang WS, Wu MF, Wu $\mathrm{MH}$, Hsia TC, Cheng SP and Bau DT: Contribution of matrix metalloproteinase-7 genotypes to the risk of non-solid tumor, childhood leukemia. Anticancer Res 37: 6679-6684, 2017.

38 Zhang J, Jin X, Fang S, Wang R, Li Y, Wang N, Guo W, Wang Y, Wen D, Wei L, Dong Z and Kuang G: The functional polymorphism in the matrix metalloproteinase-7 promoter increases susceptibility to esophageal squamous cell carcinoma, gastric cardiac adenocarcinoma and non-small cell lung carcinoma. Carcinogenesis 26: 1748-1753, 2005.

39 Sanli M, Akar E, Pehlivan S, Bakir K, Tuncozgur B, Isik AF, Pehlivan M and Elbeyli L: The relationship of metalloproteinase gene polymorphisms and lung cancer. J Surg Res 183: 517-523, 2013.

40 Shen TC, Chang WS, Tsai CW, Chao CY, Lin YT, Hsiao CL, Hsu CL, Chen WC, Hsia TC and Bau DT: The contribution of matrix metalloproteinase-1 promoter genotypes in Taiwan lung cancer risk. Anticancer Res 38: 253-257, 2018.

41 Lai CY, Chang WS, Hsieh YH, Hsu CM, Tsai CW, Chen AC, Wang $\mathrm{CH}$ and Bau DT: Association of tissue inhibitor of metalloproteinase-1 genotypes with lung cancer risk in Taiwan. Anticancer Res 36: 155-160, 2016. 
42 Pei JS, Chang WS, Hsu PC, Hung YW, Cheng SP, Tsai CW, Bau DT and Gong CL: The Contribution of MMP-8 promoter genotypes to childhood leukemia. In Vivo 31: 1059-1064, 2017.

43 Hu PS, Chang WS, Chou AK, Hsia NY, Hung YW, Lin CW, Wu CW, Huang CY, Wu MF, Liao CH, Tsai CW, Bau DT and Gong CL: The association of MMP-8 genotypes with pterygium. In Vivo 32: 41-46, 2018.

44 Tsai CW, Chang WS, Shen TC, Su CH, Wang HC, Liu LC and Bau DT: Contribution of excision repair cross-complementing group 1 genotypes to triple negative breast cancer risk. PLoS One 13: e0202112, 2018.

45 Yueh TC, Wu CN, Hung YW, Chang WS, Fu CK, Pei JS, Wu MH, Lai YL, Lee YM, Yen ST, Li HT, Tsai CW and Bau DT: The contribution of MMP-7 genotypes to colorectal cancer susceptibility in Taiwan. Cancer Genomics Proteomics 15: 207212, 2018

46 Scherf DB, Dally H, Muller P, Werle-Schneider G, Jager B, Edler L, Tuengerthal S, Fischer JR, Drings P, Bartsch H and Risch A: Single nucleotide polymorphisms in matrix metalloproteinase genes and lung cancer chemotherapy response and prognosis. Eur Respir J 35: 381-390, 2010.

47 Lin MH, Huang SJ, Shih WM, Wang PY, Lin LH and Hsu HC: Effects of an anti-smoking program to prevent lung cancer among urban aboriginals in Taiwan. Asian Pac J Cancer Prev 14: 6451-6457, 2013.

48 Cancer Registration System Annual Report 2016. Department of Health, Taiwan, 2016.

49 Yue W, Sun Q, Landreneau R, Wu C, Siegfried JM, Yu J and Zhang L: Fibulin-5 suppresses lung cancer invasion by inhibiting matrix metalloproteinase-7 expression. Cancer Res 69: 63396346, 2009.

50 Shih LC, Li CH, Sun KT, Chen LY, Hsu CL, Hung YW, Wu CN, Hsia TC, Shen TC, Chang WS, Shih TC, Tsai CW and Bau DT: Association of matrix metalloproteinase-7 genotypes to the risk of oral cancer in Taiwan. Anticancer Res 38: 2087-2092, 2018.
51 Jung YJ, Katilius E, Ostroff RM, Kim Y, Seok M, Lee S, Jang S, Kim WS and Choi CM: Development of a protein biomarker panel to detect non-small-cell lung cancer in Korea. Clin Lung Cancer 18: e99-e107, 2017.

52 Gravely S, Giovino GA, Craig L, Commar A, D'Espaignet ET, Schotte $\mathrm{K}$ and Fong GT: Implementation of key demandreduction measures of the WHO framework convention on tobacco control and change in smoking prevalence in 126 countries: an association study. Lancet Public Health 2: e166e174, 2017.

53 Liao CM, Chio CP, Chen WY, Ju YR, Li WH, Cheng YH, Liao $\mathrm{VH}$, Chen SC and Ling MP: Lung cancer risk in relation to traffic-related nano/ultrafine particle-bound PAHs exposure: a preliminary probabilistic assessment. J Hazard Mater 190: 150$158,2011$.

54 Lopez-Otin C and Matrisian LM: Emerging roles of proteases in tumour suppression. Nat Rev Cancer 7: 800-808, 2007.

55 Hsia TC, Yu CC, Hsiao YT, Wu SH, Bau DT, Lu HF, Huang YP, Lin JG, Chang SJ and Chung JG: Cantharidin impairs cell migration and invasion of human lung cancer NCI-H460 cells via UPA and MAPK signaling pathways. Anticancer Res 36: 5989-5997, 2016.

56 Safranek J, Holubec L Jr., Topolcan O, Pesta M, Klecka J, Vodicka J, Finek J, Kormunda S and Pesek M: Expression of mRNA MMP-7 and mRNA TIMP-1 in non-small cell lung cancer. Anticancer Res 27: 2953-2956, 2007.

Received September 4, 2018

Revised September 18, 2018

Accepted September 20, 2018 